\title{
Philosophy as attentive gaze
}

\author{
FILOSOFÍA COMO MIRADA ATENTA \\ JOSEP MARIA ESQUIROL \\ Universidad de Barcelona \\ jmesquirol@ub.edu
}

RECIBIDO: 17 DE DICIEMBRE DE 2016

ACEPTADO: 9 DE ENERO DE 2017

\begin{abstract}
There is something unusual, even paradoxical, about the way that we look at the world around us: the utter ease of looking contrasts with the difficulty of performing the same act well. If there is light, we just open our eyes and the things around us appear. In contrast, we must pay attention to become aware of certain aspects of reality and, in particular, to perceive things in a different way. Simply seeing, mere visual perception, involves virtually no effort (hence, for example, the success of television and screens in general), but looking with care is harder: directing our gaze and concentrating on something involves an effort and can therefore be tiring. The attentive gaze is more uncommon than we might expect. What is it that attention adds to the gaze to transform it in such a significant way? Why does the effort of directing our attention imply much more than a simple zoom effect? Philosophical gaze and attentive gaze is the same thing.
\end{abstract}

Keywords: Philosophy, attentive gaze, respect, attention

Resumen: La mirada tiene algo de extraño, de paradójico: la total facilidad de mirar contrasta con la dificultad de mirar bien. Si hay luz, con solo abrir los ojos se nos aparecen las cosas que nos rodean, pero en cambio hay que prestar atención, fijarse bien, para darse cuenta de según qué aspectos de la realidad y, sobre todo, para percibir las cosas de otra manera. El solo ver, el mero percibir visual casi no cuesta ningún esfuerzo (de ahí, por ejemplo, el éxito de la televisión y de las pantallas en general), mientras que el mirar bien, eso sí que cuesta: dirigir la mirada y concentrarse en algo supone ya un esfuerzo y acarrea, por tanto, un cansancio. La mirada atenta sea más inusual de lo que en un principio podría pensarse. ¿Qué es lo que la atención añade a la mirada, hasta el 
punto de transformarla tan significativamente? ¿Por qué el esfuerzo de la atención supone mucho más que un simple aumento de la lente? Mirada filosófica y mirada atenta coinciden.

Palabras clave: Filosofía, mirada atenta, respeto, atención

\section{The gaze of the attentive gaze}

Our senses open us to the world. In the West, sight has generally been regarded as the most powerful of the senses. We now know that sight involves light waves reaching our eyes, but historically the active and penetrating nature of the sense was often highlighted by characterising it as the point of origin for seeing, or as a kind of beam. In the 9th century, for example, the great medieval thinker John Scottus Eriugena wrote: 'For who does not know that the eye is a corporeal part of the head and that it is moist, and that it is that through which the sight pours forth from the brain like rays out of the meninx, that is, membrane. The meninx, however, receives the nature of light from the heart, that is, from the seat of fire."

And precisely because of the power of sight, western philosophy, unlike other cultural traditions, has privileged seeing over our other senses. This gives rise to interesting contrasts such as that between Greek philosophy and the Jewish tradition, which has always placed particular emphasis on hearing and the word. In the Jewish tradition, the truth is heard; in the Greek tradition it is seen or intuited. Jewish wisdom depends on listening and obeying; Greek wisdom, on intuition, seeing and clarity.

Our eyes, the organ of sight, have come to symbolise wisdom and intelligence. Indeed, they are often described as the 'windows of the soul'. Merleau-Ponty wrote: 'The eye accomplishes the

${ }^{1}$ SCOTTI ERIUGENAE, Iohannis: Periphyseon (De divisione naturae), Liber Primus, SHELDON-WILLIAMS (ed.), The Dublin Institute for Advanced Studies, Dublin, 1978. Pag. 125 [481c]. 
prodigious work of opening the soul to what is not soul - the joyous realm of things and their god, the sun. ${ }^{2}$

Given its power, however, sight can become a means of appropriation and control. Certainly, sight is an invitation to action and may provoke action: 'I see' immediately translates into 'I can'. What I look at I can also, ipso facto, act on. At the very least, part of what I see is experienced as ready-to-hand (in Heideggerian terminology). Moreover, for something to become useful, to become pragmata, it must be within our reach, and it is sight that performs the function of bringing things nearer to us. Touch, with its capacity for manipulation, is an ally of sight. So it should not surprise us that it has been said that seeing is the starting point for technology: "All techniques are based on visualization and involve visualization. ${ }^{3}$ Sight is the sense on which our efficacy depends. Without it, how could we even thread a needle? Are the plans we draft for our construction projects and machines not an emblematic example of what we set down on paper to guarantee good results based on precise measurements and clear perspectives? Without visual images, action is blind and uncertain.

Having said this, the time appears ripe for a re-examination of the primacy of sight in our cultural tradition, and possibly even to consider starting or accessing a different tradition. It is doubtful, though, whether such changes are possible, or likely rather to end up involving little more than declarations of intentions or the superficial adoption of other cultural models. In any case, the thesis of this paper is that the shift that really is possible is one concerned

2 MERLEAU-PONTY, Maurice: "Eye and Mind", in The Primacy of Perception: And Other Essays on Phenomenological Psychology, the Philosophy of Art, History and Politics, EDIE, James (trans.), Northwestern University Press, Evanston, 1964. Pag. 186.

${ }^{3}$ ELLUL, Jacques: The Humiliation of the Word, Eerdmans, Michigan, 1985. Pag. 11. 
primarily with the gaze. Within the confines of a civilisation in which sight retains its privileged status, we can nevertheless examine another dimension of that sense; one that leads us in the direction of wonder rather than control, and towards respect rather than the reduction of what we see to mere resources. Sight is, without doubt, the sense associated with efficacy, but it is also the sense of respect. While up to a point, as Ellul and others have observed, the word has been 'humiliated' in the civilisation of sight and images, things clearly could have turned out differently. There is no reason why the word and sight should be at odds when they could just as easily be allies. The attentive gaze is very closely related both to the word and to listening. A respectful attitude always implies a readiness to listen.

But we must learn how to look.

\section{Learning to look in order to see}

'The world is what we see and... nonetheless, we must learn to see it. ${ }^{, 4}$ Commentators often move directly from the contrast between sight and hearing to that between the image (what is seen) and the word (what is heard). The claim is then made that while images present everything in 'pre-processed' form, the word demands a much greater response on our part. With images our role is a passive one; the word requires that we provide greater input. This contrast, however, is a rather simplistic one, mainly because it is almost exclusively screen images that are considered (the so-called 'civilisation of the image' would be better described as the 'civilisation of the screen'). The fact is that we can still see things that do not appear on screens (though this is increasingly

4 MERLEAU-PONTY, Maurice: The Visible and the Invisible, LINGIS, Alphonso (trans.), Northwestern University Press, Evanston, 1968. Pag. 4. 
uncommon). Looking at non-screen images does require an effort on our part; the world is revealed to us, but not in an automatic fashion. Ultimately, what is revealed depends on us, so we must learn how to look. Only then will we see all that there is to see. 'What exactly does [the painter] ask of [the mountain]? To unveil the means, visible and not otherwise, by which it makes itself a mountain before our eyes. ${ }^{5}$

Virtually the same point can be made in another way. Were it the image that provided meaning, we would need only look. Given that this is clearly not the case, we need to focus on how we can look with care, which means interpreting properly what is revealed to us.

On an even more basic level, however, we must first learn to look and also to see. The first thing is to look: if we do not look, neither can we see. Sight is subject to movement. We do not see what we do not look at. 'In order to see clearly' - according to Antoine de Saint-Exupery - 'you often need to change only your line of sight.' Looking is closely linked to sight, but here we are taking a broader view that encompasses the gaze of the soul, or of the mind.

It is possible to look without seeing. As Wittgenstein says in his Philosophical Investigations: "He looked at it without seeing it." - There is such a thing. But what is the criterion for it? - Well, there is a variety of cases here. ${ }^{6}$ One can move one's head, along with the rest of one's body, and apparently even direct the gaze but still see nothing or virtually nothing of what could be seen.

How do we learn to look? We learn to look by looking, just as we learn to think by thinking. Exercise is the main teacher. Sight, we can therefore say, does not learn from anything but itself.

\footnotetext{
${ }^{5}$ MERLEAU-PONTY, Maurice: "Eye and Mind", cit., pag. 166.

6 WITTGENSTEIN, Ludwig: Philosophical Investigations, ANSCOMBE, Elizabeth (trans.), Basil Blackwell, Oxford, 1978. Pag. 211.
} 
When, for whatever reason, this capacity has not been properly applied or is subject to some kind of distortion, learning to look means looking in a new way, as if seeing things in broad daylight for the first time. Learning to look will also involve pausing to examine what is simple and what is part of our everyday experience. The most penetrating human gaze is that which is capable of detecting the extraordinary character of what is most commonplace. 'God grant the philosopher insight into what lies in front of everyone's eyes, ${ }^{7}$ wrote Wittgenstein. If the word 'philosophers' is used here in a restricted sense, then we would do well to add 'and not only philosophers'.

\section{Looking and being seen: The gaze of the world}

As Bachelard says: 'Gentleness of seeing while admiring, pride of being admired, those are human bonds. But they are active, in both directions, in our admiration of the world. The world wishes to see itself; the world lives in an active curiosity with ever open eyes. In uniting mythological dreams (songes), we can say: The Cosmos is an Argus. The Cosmos, a sum of beauties, is an Argus, a sum of ever open eyes. Thus the theorem of the reverie of vision is translated to the cosmic level: everything that shines sees, and there is nothing in the world which shines more than a look. ${ }^{8}$ That is similar to the words of Antonio Machado, the great spanish poet: 'The eye you see is not / an eye because you see it; / it is an eye because it sees you.'

The penetration of sight can reach 'extremes' when we perceive the world as something that looks at us.

WITTGENSTEIN, Ludwig, Culture and Value, WINCH, Peter (trans.), Basil Blackwell, Oxford, 1980. Pag. 63.

${ }^{8}$ BACHELARD, Gaston: The Poetics of Reverie. Childhood, Language, and the Cosmos, RUSSELL, Daniel (trans.), Bacon Press, Boston, 1969. Pags. 185-186. 
My gaze makes me the centre of the world by placing me at the point from which I see everything, and everything is thus relative to the point from which I see it. Perhaps we have not given enough thought to the obvious fact that the act of looking makes each of us the centre of the world. I think this inevitable perceived centrality should be counterbalanced. It should not be negated (what price would we pay if we negated the subject?), but does need to be offset: first, by the certainty that other subjects also perceive themselves as central; and second, by the idea that the world we look upon can also, in a manner of speaking, look back at us. This may sound odd and disturbing. It does not negate my centrality, but qualifies it by pointing to a possibility (not a fact). The disturbing nature of this hypothesis is reflected in an anecdote recounted by Lacan about an incident that took place when he was a young man: 'One day, I was on a small boat, with a few people from a family of fishermen in a small port (...) One day, then, as we were waiting for the moment to pull in the nets, an individual known as Petit-Jean (...) pointed out to me something floating on the surface of the waves. It was a small can, a sardine can. It floated there in the sun, a witness to the canning industry, which we, in fact, were supposed to supply. It glittered in the sun and Petit-Jean said to me: "You see that can? Do you see it? Well, it doesn't see you!" He found this incident highly amusing - I less so. I thought about it. Why did I find it less amusing than he? It's an interesting question. To begin with, if what petit-Jean said to me, namely, that the can did not see me, had any meaning, it was because in a sense, it was looking at me all the same. It was looking at me at the level of the point of light at which everything that looks at me is situated - and I am not speaking metaphorically. ${ }^{, 9}$ The anecdote suggests something very similar to the experience described by the painter Paul Klee: 'In a

9 LACAN, Jacques: The Four Fundamental Concepts of Psychoanalysis, SHERIDAN, Alan (trans.), Penguin Books, London, 1994. Pag. 95. 
forest I have felt many times that it was not I who looked at the forest. Some days I have felt that the trees were looking at me...'

In my view, we do not need to revive any form of animism to achieve a richer and more complex view of the world. While it is true that I am at the centre when it comes to my own perception, I am also aware that there are other 'centres' of perception, which I call people, and others, such as animals, which have distinct perceptual capacities, and plants, which as living organisms are sensitive to their surroundings. Moreover, the material we describe as 'inert' interacts with us. This interaction need not be understood within the framework of the Leibnizian theory of universal perception; it is enough to be open to the implications of quantum theory concerning interaction of elementary particles.

In short, my aim in relating these anecdotes (selected from among many that could be used to make the same point) is only to recommend that we look with greater care and put more effort into perception. Paradoxically, when we look with care, we are as likely to become aware of our own relative insignificance as of our centrality.

\section{Paying attention and the spiral of attention}

Learning to look essentially means learning to pay attention. People often say 'If you pay attention, you will see that...' This is the key: paying attention is a condition for seeing or becoming aware of something, as well as a way to accomplish this.

What is attention, though? We could characterise it in almost the same way as the gaze. Like the gaze, attention is a kind of 'spotlight'. 'It is usual to compare attention with an illuminating 
light,' wrote Husserl. ${ }^{10} \mathrm{He}$ also used the expressions 'mental glance' and 'glancing ray', referring to the directing of the ego towards something and the way it is deflected back. Our attention can shift, for instance, from something in the external world to something in our own consciousness, and can also move in the opposite direction. Attention, then, is also a movement. The shifts it involves occur within the field of consciousness: 'Ultimately it extends [the range of the unitary notion of attention] as far as the concept: consciousness of something. ${ }^{11}$ This is not, however, simply a matter of two things coinciding in the same field. Paying attention and being conscious are closely linked. A minimum level of attention is needed to be conscious of something, and attention depends on consciousness: they are two sides of the same coin. Merleau-Ponty describes this relationship as follows: 'For it to gain possession of the knowledge brought by attention, it is enough for it to come to itself again, in the sense in which a man is said to come to himself again after fainting. On the other hand, inattentive or delirious perception is a semi-torpor, describable only in terms of negations, its object has no consistency, the only objects about which one can speak being those of waking consciousness., ${ }^{12}$

Attention is a kind of activity ('paying attention' implies focusing and selecting), but also a state ('being focused, alert, etc.'). As a state it contrasts with being unfocused, sleepy or distracted. William James, one of the founders of modern psychology, gave a clear description of what attention involves: 'Focalisation, concentration, of consciousness are of its essence. It

${ }^{10}$ HUSSERL, Edmund: Ideas: General Introduction to Pure Phenomenology, W. R. BOYCE GIBSON, W.R., (trans.), George Allen/Humanities Press, London/New York. 1969, § 92, pag. 269.

${ }^{11}$ HUSSER, Edmund: Logical Investigations, vol. I, FINDLAY, J. N. (trans), Humanity Books, New York, 2000. Pag. 384.

${ }^{12}$ MERLEAU-PONTY, Maurice: Phenomenology of Perception, SMITH, Colin (trans.), Routledge, London/New York, 1962. Pag. 27. 
implies withdrawal from some things in order to deal effectively with others, and is a condition which has a real opposite in the confused, dazed, scatter-brained state which in French is called distraction, and Zerstreutheit in German. ${ }^{13}$

Attention means leaving behind a state characterised by a certain lack of focus, sleepiness or immersion in the flow of things. In relation to the idea of sleepiness, attention is an awakening; seen as a movement away from lack of focus, distraction and flow, attention is an activity that arises from the self, an effort that consists in taking oneself out of the stream of the impersonal in order to come to a stop. Extracting ourselves from this flow to come to a stop is harder than we might think, though. We are in the habit of letting ourselves drift, and grow accustomed to not making an effort and to the ease this brings.

Of course, to come to a stop does not mean to hesitate. It is the condition that makes attention possible. We can perceive things, or at least perceive them precisely, only when we come to a stop. To become aware of the progress of the sun, or the rhythm of our own breathing, we must come to a halt. Oddly, this stillness makes us visionaries. It is not those who are in the greatest hurry or who are most mobile that see most, it is those who are capable of coming to a stop. In our increasingly fast-paced society this is something we can experience very intensely on the rare occasions when we manage to make ourselves pause. Given that we spend most of our time immersed in the impersonal in a thousand different ways, when we extract ourselves from this flow we are at first disconcerted (indeed, we often find it hard to tolerate solitude and silence), but then we begin to see.

Needless to say, we need not take pause in any special place. For this purpose, all places are privileged: the profound is to be

13 JAMES, William: The Principles of Psychology, The University of Chicago/Encyclopaedia Britannica, Chicago/London, 1952. Pag. 261. 
found in the everyday. Neither do we need to travel to remote and exotic locations. Anyone unable to see what is surprising and beautiful in their immediate surroundings will not find these qualities in far-off lands either. Familiarity all too often immerses us in routine, and to a large degree the everyday is the river of inattention that sweeps us along. In his analysis of the mode of being of what is 'ready-to-hand' in Being and Time, Heidegger writes: 'The readiness-to-hand which belongs to any such region beforehand has the character of inconspicuous familiarity, and it has it in an even more primordial sense than does the Being of the ready-to-hand. ${ }^{, 14}$ What I am most interested in underlining in this text is the fact that these 'regions' that surround and are familiar to us do not attract our attention. The same applies to 'things', which means that familiarity (habit, routine, etc.) results in a certain degree of inattention and leads us to become dispersed among things. This probably happens because this approach is not too tiring and we need not expend much energy. We like to let ourselves go with the flow. All of this highlights the dangers inherent in the everyday. The most serious of these concern what we no longer perceive due to the state of inattention we are drawn into. Even when we are immersed in the everyday, though, this situation can be turned around. We can stop, and when we do the simple and commonplace character of the familiar can be revealed to us in all its strangeness and profundity.

In addition to the possibilities of awakening and taking pause, we also need to examine the idea of receiving, or, more accurately, of emptying ourselves in order to receive. Although this idea contrasts with the image of attention as a spotlight, there is no contradiction in saying that attention involves a kind of heightening and broadening of our capacity to perceive. In order to receive one

14 HEIDEGGER, Martin: Being and Time, MACQUARRIE, John \& ROBINSON, Edward (trans.), Harper \& Row, New York, 1962. Pags. 137-138. 
must have free space available and a very flexible 'opening'. Otherwise, how is the other to enter? Contrary to what is often thought attention does not imply rigidity. Rigidity of any kind hinders perception. This misunderstanding is nevertheless widespread, particularly in the field of education. According to Simone Weil: 'To pay attention, it is necessary to know how to set about it. Most often attention is confused with a kind of muscular effort. If one says to one's pupils: "Now you must pay attention," one sees them contracting their brows, holding their breath, stiffening their muscles. If after two minutes they are asked what they have been paying attention to, they cannot reply. They have been concentrating on nothing. They have not been paying attention. They have been contracting their muscles. ${ }^{, 15}$ The effort of attention does not require that any muscle be contracted. Attention is a tension (paying attention is like drawing a bow), but this tension does not involve muscular rigidity (Rodin's famous sculpture, The Thinker, is therefore not very lifelike: all of the effort made by the figure is being applied to tense his muscles). It is a different kind of tension that must come into play when we pay attention, and it must be a flexible tension like that of the archer's bow.

Together with flexibility and tension, an emptying is also necessary. An emptying and a detachment from the self must be achieved. Our thoughts must be suspended so that our minds are more available and penetrable. We must put aside our own 'baggage' (at least momentarily) so that we can move away from our own centre. Attention requires that we do not allow ourselves to be diluted in the impersonal; that we do not cling to what is ours; and that we do not fill ourselves with easy certainties. We must avoid becoming dispersed in everything, but let go of ourselves a

${ }^{15}$ WEIL, Simone: Waiting on God, CRAUFURD, Emma (trans.), Routledge and Keagan, London, 1951. Pag. 54. 
bit so that we can be more authentically ourselves. The act of paying attention is somewhat paradoxical: the effort the subject must make does not involve being more present, but rather a reduction or emptying, and an opening towards the other. The subjective intensity of attention involves making a space available to receive something or allow entry to the object that is the focus of attention. Not paying attention means remaining closed or too impenetrable to the influence of the other. Particularly helpful in illustrating this point are C. S. Lewis' reflections on how to look at paintings (that is, how to direct our attention at them), which are found in an essay on the experience of reading. Lewis says that when we look at a painting most of us tend to make 'use' of it in some way. In other words, we do something with the painting instead of opening ourselves to it so that it can do something in us. In particular, we make use of paintings when we do not give them the attention they deserve: "We must not let loose our own subjectivity upon the pictures and make them its vehicles. We must begin by laying aside as completely as we can all our own preconceptions, interests, and associations. We must make room for Botticelli's Mars and Venus, or Cimabue's Crucifixion, by emptying out our own. After the negative effort, the positive. We must use our eyes. We must look, and go on looking till we have certainly seen exactly what is there. We sit down before the picture in order to have something done to us, not that we may do things with it. The first demand any work of any art makes upon us is surrender. Look. Listen. Receive. Get yourself out of the way. ${ }^{16}$ The passage describes very well what it means to pay attention: 'look, and go on looking till we have certainly seen exactly what is there' and at the same time receive. Lewis says the same about both painting and literature. All the examples he gives underscore the

\footnotetext{
${ }^{16}$ LEWIS, Clive: An Experiment in Criticism, Cambridge University Press, Cambridge, 1961. Pag. 16 .
} 
fact that only true attention can take us outside ourselves, and in so doing allow us to learn. In this light, attention is seen as a struggle against self-absorption. There is no other struggle as worthwhile as this one can end up being. This perspective also allows us to understand that insufficient attention implies insufficient respect. When we focus on ourselves - on our own ideas, interests, opinions and desires - we become incapable of receiving the other, and therefore incapable of respecting it.

The need for flexibility must be stressed. There is a kind of attention that in the end does not deserve to be described as such, and, in fact, hinders perception. It is important to realise that there are no models or standards for defining attention. The image of the spotlight is probably a good one, but so are the ideas of flexibility and receiving. The fact that a spotlight is directed at something specific suggests concentration. In contrast, the notion of receiving involves opening up to the other. Could it be that a certain kind of concentration is inflexible and allows only limited opening to the other? In my view, we should not give up either image: together they show us how rich an activity paying attention is. Sometimes we need to focus in order to pay attention; on other occasions we need to open ourselves up. Sometimes I experience a form of attention with virtually no object. Nevertheless, this state keeps me open and alert to what is around me and to its demands. Other times, attention is more focused, and involves looking at and examining something specific. At times, despite a great deal of opening, we perceive nothing; on other occasions, too much focus yields the same result. It may even be the case that optimal attention involves striking a balance between these two approaches, and that too great an emphasis on either diminishes our capacity to see.

In any case, flexibility is always essential. Even when focusing our attention, we must take an unhurried approach, freeing ourselves of any pressures and especially of any preconceived 
notions. Throwing ourselves into the task of paying attention will be utterly counterproductive. The best form of attention arises from a state of relative calm. Attention is not a kind of spiritual determination with which we nail objects down: its application should be a mild and serene process. I do not see attention as a form of strict and continuous abstraction. Indeed, I would count those who are self-absorbed among the distracted as surely as those who are scatterbrained. Neither has achieved the right kind of attention. Attention should be firm but mild. We should work to acquire the flexibility needed to shift our attention from one object to another as required by the course of events. The secret is to achieve a form of attention that is steady without being unyielding, and flexible without being slack.

Given this understanding of attention, my meaning will now be clear when I speak of how it can benefit us in terms of our growth as individuals. True knowledge comes from looking attentively and systematically in the right direction. Patience in paying attention leads to significant insights and discoveries.

As I have already mentioned, attention is learned through exercise: paying attention is habit-forming. It is a skill at which we become proficient by virtue of constant exercise. The effort we make today may bear fruit tomorrow in a way that is completely unforeseeable. Weil also has something to say on this point: 'If we concentrate our attention on trying to solve a problem of geometry, and if at the end of an hour we are no nearer to doing so than at the beginning, we have nevertheless been making progress each minute of that hour in another more mysterious dimension. Without our knowing or feeling it, this apparently barren effort has brought more light into the soul. The result will one day be discovered in prayer. Moreover it may very likely be felt besides in some department of the intelligence in no way connected with mathematics. Perhaps he who made the unsuccessful effort will one day be able to grasp the beauty of a line of Racine more vividly on 
account of it. ${ }^{, 17}$ Not surprisingly, Weil believes that the fundamental goal of education should be precisely to 'exercise attention'.

The acuity attention can be applied in countless different ways. It allows us to perceive specific aspects of physical reality, and can also be applied in the moral sphere. It can detect what relates to beauty, or to technical efficiency, and also what is concerned with goodness or justice. The value of things and actions is revealed to the attentive gaze, and what is just or good takes on a natural primacy from such a perspective. Painting aspires to be recognised as beautiful; just action aspires to be preferred over a lie...

Attention is fundamental to our sense of morality, but this does mean that we should not also recognise the value of moral reasoning. I do believe, however, that there is something crucial to our sense of morality that does not emerge from the lengthy and arduous application of reason. This view is one I think many share, among them Rousseau. Leaving aside the question of whether or not Rousseau contradicted himself on this point, I will refer only briefly to what he says in his Discourse on the Origin and Foundations of Inequality Among Men, ${ }^{18}$ where he speaks of compassion, which he understands as repugnance at seeing a fellow-creature suffer. Rousseau argues that compassion is a natural feeling that even beasts show signs of. He stresses that this feeling precedes the exercise of reason, and therefore is not a product of it. For Rousseau, the conclusion that I should feel repugnance in the face of the suffering of other creatures is not one arrived at after lengthy digressions: it is a feeling I experience naturally and spontaneously. Nevertheless, might this feeling not depend on a minimum level of attention? Rousseau gets to the heart

\footnotetext{
${ }^{17}$ WEIL, Simone: op. cit., pag. 52.

18 ROUSSEAU, Jean-Jacques: 'The Discourses' and Other Early Political Writings, GOUVERICH, V. (ed.), Cambridge University Press, Cambridge, 1997.
} 
of the matter when he criticises the philosopher, shut away in his room, who 'only has to put his hands over his ears and to argue with himself a little' to ignore the fact that a murder is being committed with impunity beneath his window. This so-called philosopher pays no attention to what is going on around him. Instead, he uses the exercise of reason to isolate and distract himself. Rousseau continues in an ironic tone: 'Savage man has not this admirable talent'. ${ }^{19}$ Clearly he is referring not to the capacity to pay attention, but to the ability to turn off one's attention so as to better evade what it might reveal. Uncivilised man is doubtless unacquainted with any ethical theory, but he does have the capacity to pay attention, to look with care, and this is precisely what is most important. Civilised man, on the other hand, can study and learn about wonderful philosophical systems and sophisticated moral theories, but his ability to pay attention may be atrophied or intentionally put aside, leaving him incapable of contact with the world around him.

The pseudo-philosopher covers his ears, avoids looking out the window and goes off on tangents, and in so doing ceases to pay attention to his situation. I am particularly interested in Rousseau's observation that philosophy (false philosophy) isolates us from things and from others. This kind of philosophy turns off our natural compassion, cutting us off from the world. Attention, on the other hand, connects us to the world, to its density and novelty (as Arendt would say). The atrophy of our sense of morality follows naturally from the atrophy of our capacity to be in the world and recognise its continuous novelty.

In my view, Arendt is absolutely right when she says that one of the most important characteristics of totalitarianism is its practical identification of control, security, absence of novelty and rejection of the world. There are certain parallels between the distractions of the

${ }^{19}$ ROUSSEAU: op. cit., pag. 153. 
pseudo-philosopher and the experience of mass man in totalitarian regimes. In such regimes, the individual's knowledge and vision of the world tend to be governed exclusively by the coherence of an 'ideology', rather than by experience or contact with the reality of the world. The masses leave reality and the world behind because novelty is a natural part of that world; the coherence of the prevailing theory is more comforting and safer than continually dealing with the novelty of the world and the demands it makes. The resulting isolation means life without the world and without identity: 'Self and world, capacity for thought and experience are lost at the same time. $^{20}$ There are many ways to isolate oneself, some more sophisticated than others. There are theories that insulate us from the world and its demands under the pretext of sheltering and protecting us (though these may more accurately be described as 'ideologies' in the worst sense of the word). ${ }^{21}$

In Husserlian terms, ideology evacuates the meaning inherent in the world of life and absolutises logical relation. The latter, cut adrift from reality, can be adopted by individuals without their capacity for reflection or experience of the world ever coming into play. Individuals can apply the logical system without thought and without reference to the world.

Attention connects us to the world, and this link is our best vaccine against dogmatism, slogans, ideologies and languages that

\footnotetext{
${ }^{20}$ ARENDT, Hannah: The Origins of Totalitarianism, Harcourt Brace, New York, 1973. Pag. 477.

${ }^{21}$ Ideology, understood literally as the logic of an idea, is, according to Arendt, the backdrop to totalitarianism. And what Arendt says about political totalitarianism parallels an observation made by Levinas about the philosophical tradition of the West: "Philosophy itself is identified with the substitution of ideas for persons, the theme for the interlocutor, the interiority of the logical relation for the exteriority of interpellation." LEVINAS, Emmanuel: Totality and Infinity. An Essay on Exteriority, LINGIS, Alphonso (trans.), Duquesne University Press \& Martinus Nijhoff, Pittsburgh \& The Hague, 1969. Pag. 88.
} 
seem technical but are in fact empty. This connection also safeguards us against the atrophy of our moral feeling. Without it and without our experience of things and others, everything tends to become contrived. Words lack meaningful content; what we say does not respond to anything or anyone (for we are no longer capable of listening or of feeling that we are engaged in a dialogue, and no longer grasp the requirements of each situation). In the absence of this connection, theories focus on evasion, mere play or security, rather than pursuing a sense of direction and meaning.

In making these points I have two aims in mind: first, to indicate the parallel between the role I am assigning to attention and that which other authors such as Rousseau and Scheler have attributed to moral feeling; and second, to highlight the close relationship between attention, contact with the world, and reflection, which is also highly significant in the moral sphere.

\section{References}

ARENDT, Hannah: The Origins of Totalitarianism, Harcourt Brace, New York, 1973.

BACHELARD, Gaston: The Poetics of Reverie. Childhood, Language, and the Cosmos, RUSSELL, Daniel (trans.), Bacon Press, Boston, 1969.

ELLUL, Jacques: The Humiliation of the Word, Eerdmans, Michigan, 1985.

HEIDEGGER, Martin: Being and Time, MACQUARRIE, John \& ROBINSON, Edward (trans.), Harper \& Row, New York, 1962.

HUSSERL, Edmund: Ideas: General Introduction to Pure Phenomenology,W. R. BOYCE GIBSON, W.R., (trans.), George Allen/Humanities Press, London/New York. 1969.

JAMES, Willim: The Principles of Psychology, The University of Chicago/Encyclopaedia Britannica, Chicago/London, 1952. 
LACAN, Jacques: The Four Fundamental Concepts of Psychoanalysis, SHERIDAN, Alan (trans.), Penguin Books, London, 1994.

LEVINAS, Emmanuel: Totality and Infinity. An Essay on Exteriority, LINGIS, Alphonso (trans.), Duquesne University Press \& Martinus Nijhoff, Pittsburgh \& The Hague, 1969.

LEWIS, Clive: An Experiment in Criticism, Cambridge University Press, Cambridge, 1961.

MERLEAU-PONTY, Maurice: "Eye and Mind", in The Primacy of Perception: And Other Essays on Phenomenological Psychology, the Philosophy of Art, History and Politics, EDIE, James (trans.), Northwestern University Press, Evanston, 1964.

Phenomenology of Perception, SMITH, Colin (trans.), Routledge, London/New York, 1962.

The Visible and the Invisible, LINGIS, Alphonso (trans.), Northwestern University Press, Evanston, 1968.

ROUSSEAU, Jean-Jacques: 'The Discourses' and Other Early Political Writings, GOUVERICH, V. (ed.), Cambridge University Press, Cambridge, 1997.

SCOTTI ERIUGENAE, Iohannis: Periphyseon (De divisione naturae), Liber Primus, SHELDON-WILLIAMS (ed.), The Dublin Institute for Advanced Studies, Dublin, 1978.

WEIL, Simone: Waiting on God, CRAUFURD, Emma (trans.), Routledge and Keagan, London, 1951.

WITTGENSTEIN, Ludwig: Culture and Value, WINCH, Peter (trans.), Basil Blackwell, Oxford, 1980.

Logical Investigations, vol. I, FINDLAY, J. N. (trans), Humanity Books, New York, 2000.

Philosophical Investigations, ANSCOMBE, Elizabeth (trans.), Basil Blackwell, Oxford, 1978. 


\section{COMENTARIOS, INFORMES Y ENTREVISTAS}

\section{STUDIES, REPORTS AND INTERVIEWS}


